\title{
Profile of nursing diagnoses in indigenous older adults in the community: a cross-sectional study
}

Perfil dos diagnósticos de enfermagem em idosos indígenas na comunidade: estudo transversal

Perfil de los diagnósticos de enfermería en ancianos indígenas de la comunidad: un estudio transversal

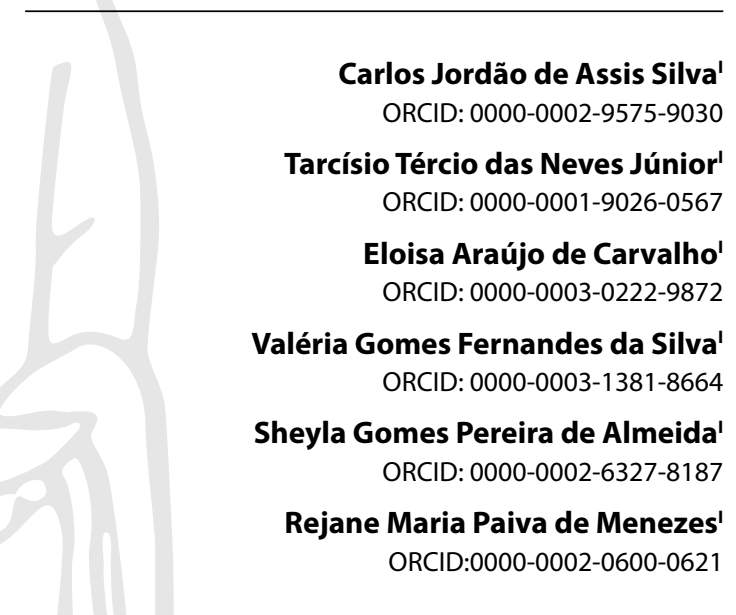

'Universidade Federal do Rio Grande do Norte. Natal, Rio Grande do Norte, Brazil.

How to cite this article: Assis Silva CJA, Neves Júnior TT, Carvalho EA, Silva VGF, Almeida SGP, Menezes RMP. Profile of nursing diagnoses in indigenous older adults in the community: a cross-sectional study. Rev Bras Enferm. 2022;75(2):e20210128. https://doi.org/10.1590/0034-7167-2021-0128

Corresponding author:

Carlos Jordão de Assis Silva

E-mail: carlosjrdao@gmail.com

EDITOR IN CHIEF: Antonio José de AlmeidaFilho ASSOCIATE EDITOR: Ana Fátima Fernandes

Submission: $04-21-2020$

Approval: 05-10-2021

\begin{abstract}
Objective: to describe the profile of nursing diagnoses evidenced in indigenous elderly in the community. Methods: this is a cross-sectional study, carried out with 51 indigenous elderly people of Potiguara ethnicity, through a nursing consultation. The clinical data, obtained from the consultation, were analyzed following Risner's diagnostic reasoning process and the NANDA-I Taxonomy (2018-2020). For greater accuracy, the diagnoses obtained underwent peer review by a specialist. Results: 37 diagnoses were identified, such as Impaired dentition (98.0\%), Risk for impaired skin integrity (66.7\%), Chronic pain (64.7\%), Risk for deficient fluid volume (54.9\%), Impaired swallowing (45.1\%), Impaired walking (45.1\%), Disturbed sleep pattern (43.1\%), Stress urinary incontinence (41.2\%), Risk for falls (35.3\%), and Sexual dysfunction (33.3\%). Conclusion: the diagnoses identified were predominantly from Safety/protection domain and result from factors that negatively influence indigenous elderly's functional capacity.

Descriptors: Health of the Elderly; Indigenous Population; Nursing Diagnosis; Geriatric Nursing; Transcultural Nursing.
\end{abstract}

\section{RESUMO}

Objetivo: descrever o perfil dos diagnósticos de enfermagem evidenciados em idosos indígenas na comunidade. Métodos: trata-se de um estudo transversal, realizado com 51 idosos indígenas de etnia Potiguara, mediante consulta de enfermagem. Os dados clínicos, obtidos a partir da consulta, foram analisados seguindo o processo de raciocínio diagnóstico de Risner e a Taxonomia da NANDA-I (2018-2020). Para maior acurácia, os diagnósticos obtidos passaram por revisão pareada por especialista. Resultados: identificaram-se 37 diagnósticos, dentre eles, Dentição prejudicada (98,0\%), Risco de integridade da pele prejudicada $(66,7 \%)$, Dor crônica (64,7\%), Risco de volume de líquido deficiente (54,9\%), Deglutição prejudicada $(45,1 \%)$, Deambulação prejudicada (45,1\%), Distúrbio no padrão de sono $(43,1 \%)$, Incontinência urinária de esforço (41,2\%), Risco de quedas (35,3\%) e Disfunção sexual (33,3\%). Conclusão: os diagnósticos identificados foram predominantemente do domínio Segurança/proteção e resultam de fatores que influenciam negativamente a capacidade funcional do idoso indígena. Descritores: Saúde do Idoso; População Indígena; Diagnóstico de Enfermagem; Enfermagem Geriátrica; Enfermagem Transcultural.

\section{RESUMEN}

Objetivo: describir el perfil de los diagnósticos de enfermería evidenciados en ancianos indígenas de la comunidad. Métodos: se trata de un estudio transversal, realizado con 51 ancianos indígenas de la etnia Potiguara, mediante consulta de enfermería. Los datos clínicos, obtenidos de la consulta, fueron analizados siguiendo el proceso de razonamiento diagnóstico de Risner y la Taxonomía NANDA-I (2018-2020). Para mayor precisión, los diagnósticos obtenidos se sometieron a una revisión por pares por parte de un especialista. Resultados: se identificaron 37 diagnósticos, entre ellos, Alteración de la dentición (98,0\%), Riesgo de alteración de la integridad de la piel $(66,7 \%)$, Dolor crónico $(64,7 \%)$, Riesgo de deficiencia de volumen de líquido (54,9\%), Alteración de la deglución (45,1\%), Deterioro de la marcha $(45,1 \%)$, Alteración del patrón de sueño $(43,1 \%)$, Incontinencia urinaria de esfuerzo (41,2\%), Riesgo de caídas (35,3\%) y Disfunción sexual (33,3\%). Conclusión: los diagnósticos identificados fueron predominantemente del dominio Seguridad/protección y resultan de factores que influyen negativamente en la capacidad funcional de los ancianos indígenas. Descriptores: Salud del Anciano; Población Indígena; Diagnóstico de Enfermería; Enfermería Geriátrica; Enfermería Transcultural. 


\section{INTRODUCTION}

The increase in the number of elderly people in the population is real and directly impacts on health systems and services ${ }^{(1)}$. The Brazilian population is also experiencing this process of demographic transition. According to data from the Brazilian Institute of Geography and Statistics (IBGE - Instituto Brasileiro de Geografia e Estatística), the current proportion of elderly people in Brazil is 12.3\%, and projections indicate that, by the year 2030, this number will rise to $18.73 \%{ }^{(2)}$.

This population aging occurs similarly among indigenous peoples, who share universal aging needs, especially regarding physiological and psychosocial changes, thus making them susceptible to frailty, the development of health problems and greater dependence on care $^{(3)}$.

However, in addition to universal issues, the aging process is strongly influenced by a person's life history in their different forms of social insertion throughout life and their exposure to contexts of vulnerability ${ }^{(4)}$. Thus, the difficulty of accessing or even exclusion from material and immaterial goods, such as health services, lead indigenous elderly people to live in an undignified manner and suffer preventable health and death problems $s^{(5)}$.

Therefore, it is believed that Primary Health Care (PHC) services are able to reorganize and coordinate the provision of comprehensive care considering the specific demands of indigenous elderly. This alternative includes expanding access to health and, consequently, reducing health inequities ${ }^{(4)}$. Also at this level of care, nurses structure their care through the nursing process (NP), which, when performed in outpatient health services, households, as in the case of PHC, corresponds to the nursing consultation $(\mathrm{NC})^{(6-7)}$.

NC is characterized as an important technological instrument to identify and diagnose human responses, aiming at the prescription and implementation of nursing interventions. In addition, NC is composed of the steps of nursing history, nursing diagnosis, planning, implementation and also assessment of nursing outcomes achieves ${ }^{(6)}$.

Nurses, according to Resolution 358/2009 of the Federal Nursing Council, are responsible for the steps of nursing diagnosis (ND) and the prescription of nursing interventions against the identified ND. Thus, the ND is a stage of the NC, through which a clinical judgment is made about the individual, family or community's response to their potential or actual health problems, in addition to guiding nurses' decision making ${ }^{(6,8)}$.

Although the importance of this technology for nurses' clinical practice is evident, and it is also a legal obligation, it is seen that its use in Brazil still occurs in a withdrawn way and is restricted, in most cases, to hospital services ${ }^{(9)}$, which weakens nursing care in PHC.

Added to this problem is the scarcity of Brazilian studies that address elderly's health conditions from an ethnic-racial perspective $^{(10)}$, especially indigenous elderly people, about whom the literature still presents fragmented and discrepant data, raising doubts about who they are and how do these elderly people live. This theme, however, is signaled as essential by the Brazilian National Agenda of Priority in Health Research (Agenda Nacional de Prioridade em Pesquisa em Saúde), which points out the need for studies related to the magnitude and dynamics of problems related as elderly's health as well to indigenous health ${ }^{(11)}$.

On the development of research on NDs in Brazilian graduate programs, there are few studies aimed at the elderly population, representing less than $10 \%$ of the research carried out ${ }^{(12)}$. Regarding indigenous health, specifically, no studies were found with the theme of NDs. Thus, in this study, the human responses of indigenous elderly people of the Potiguara ethnic group, who speak Portuguese, were investigated.

It is understood that the results of this study can support the strengthening of $\mathrm{NC}$ and nurses' diagnostic reasoning through the description of the profile of the NDs found in this population and, consequently, provide possibilities for improvement and greater resolvability of nursing care for the indigenous elderly in PHC. Furthermore, it is estimated that the results can contribute to the strengthening of nurses' professional identity through the use of their own theoretical constructs, such as standardized nursing languages.

Given the above, the research question is: what are the NDs present in indigenous Potiguar (Potiguar is the name of a large Tupi tribe that inhabited the coastal region of what are now the states of Rio Grande do Norte and Paraíba) elderly in the community?

\section{OBJECTIVE}

To describe the profile of nursing diagnoses evidenced in indigenous elderly in the community.

\section{METHODS}

\section{Ethical aspects}

This study was approved by the Institutional Review Board (IRB) of Universidade Federal do Rio Grande do Norte and by the Brazilian National Research Ethics Commission (CONEP - Comissão Nacional de Ética em Pesquisa). To carry out the study, authorization was also obtained from the indigenous leadership. Only after this, the process of submitting the project to the IRB-CONEP system was continued. After approval, data collection was started.

\section{Study design, period, and place}

This work is a cross-sectional study, methodologically guided by the STROBE instrument. It was held in an indigenous community in Rio Grande do Norte during August 2019.

\section{Population or sample; inclusion and exclusion criteria}

We worked with elderly people's ethnic identity and their feeling of belonging to the Potiguara indigenous group, especially the studied group in question; therefore, elderly indigenous people from the Potiguara ethnic group participated in the research. According to the indigenous leadership, 61 elderly indigenous people lived in the community; thus, it was decided to work with all subjects so that the description of the profile of human responses would faithfully represent the population.

Subjects aged 60 years and older, who declare themselves indigenous and residing in the community, were included. 
Subjects absent from the community during the data collection period were excluded.

During data collection, it was noticed that three elderly people had died, three were absent from the community and four denied participation in the study, making a total of 51 participants.

\section{Study protocol}

The data collection technique was NC, guided by the use of a structured instrument divided into sociodemographic data and nursing history with physical examination. The aforementioned instrument was elaborated by the researcher, based on data from the gerontogeriatic literature focused on Comprehensive Geriatric Assessment (CGA) and on Primary Care Booklet no 19 - elderly's health and aging. The instrument had open-ended and closedended questions, subdivided into 12 NANDA-I domains (Health promotion, Nutrition, Elimination and exchange, Activity/rest, Perception/cognition, Self-perception, Role relationship, Sexuality, Coping/stress tolerance, Life principles, Safety/protection, Comfort). Growth/development domain was excluded, as it does not have compatible ND for the elderly population.

Regarding the recruitment of participants, when approaching the indigenous elderly, an invitation was made to participate in the research, with the Informed Consent Form (ICF) being provided, in compliance with the recomemendations established by Resolution 510/16 and 304/200 of the Brazilian National Health Council (Conselho Nacional de Saúde). For participants who were unable to read the ICF, was performed the reading in the presence of an impartial witness without involvement with the research, and, on that occasion, the doubts that arose were clarified. If the elderly person agreed to participate, they were asked to sign the term.

Data collection was carried out exclusively by the main researcher of the study, who had previous contact with the indigenous community. The place to carry out data collection was the participants' homes, whose addresses were provided by the indigenous leadership. During the collection, a representative of the leadership accompanied the researcher daily.

\section{Analysis of results, and statistics}

Clinical data, obtained through NC, were analyzed following the steps of Risner's diagnostic reasoning process ${ }^{(13)}$. Step 1 consisted of data analysis and synthesis, through data categorization procedures, identification of divergent data or gaps, grouping of evidence into patterns, comparison of patterns with theories, models, norms and concepts, identification of possibilities and proposition of causal relationships; step 2, on the other hand, constituted the establishment of the NDs themselves, with the naming of human responses.

To compose the diagnostic statements, NANDA-I Taxonomy (2018-2020) was used, considering its components (title, related factors/risk factors and defining characteristics). To promote greater reliability to the NDs, all the diagnostic statements were prepared based on the NANDA-I guidelines, in addition to having been revised by consensus by the main researcher and the advisor, both with expertise in the area of NDs and gerontological nursing.
In case of disagreement, a third expert, also with experience in the area, was consulted to review the proposed ND.

The NDs and their components entered into a database. These data were analyzed using the Statistical Package for the Social Sciences (SPSS), 20.0 software. Analysis was performed using descriptive statistics, using relative and absolute frequencies, as well as their respective confidence intervals $(95 \% \mathrm{Cl})$. Finally, the minimum, maximum, mean and standard deviation measures were also calculated.

Regarding the analysis of related factors/risk factors and defining characteristics, those diagnoses were considered with a frequency of $30 \%$. In the literature, studies ${ }^{(14-15)}$ were observed that analyzed diagnoses with a frequency greater than $50 \%$; however, it was understood that the NDs identified with a frequency greater than $30 \%$ in this study represented important health conditions for nursing care gerontological, as they relate to geriatric syndromes.

\section{RESULTS}

Among the elderly, the majority were female (58.8\%) and aged between 60 and 79 years old (74.5\%). Regarding the NDs identified, the mean of diagnoses by the elderly was 8.12. Regarding the distribution by NANDA-I domains, as shown in Table 1, domain 11 , Safety/protection, had the highest mean of diagnoses (2.29), while domains 6 and 10, Self-perception and Life principles, did not have any diagnosis present.

Table 2 presents the NDs found, their frequencies and confidence intervals. In total, 37 diagnoses were found, and those with frequencies above 30\%, Impaired dentition (98.0\%), Risk for impaired skin integrity (66.7\%), Chronic pain (64.7\%), Risk for deficient fluid volume (54.9\%), Impaired swallowing (45.1\%), Impaired walking (45.1\%), Disturbed sleep pattern (43.1\%), Stress urinary incontinence (41.2\%), Risk for falls (35.3\%), and Sexual dysfunction (33.3\%).

Of these 37 diagnoses, $78.4 \%$ were problem-focused diagnoses, $18.9 \%$ were risk diagnoses, and $2.7 \%$ were health promotion diagnoses. 1 ND of syndrome, Frail elderly syndrome, was observed. Of the total, 10 NDs had a frequency $\geq 30 \%$. These NDs had 11 related factors, 11 risk factors and 30 defining characteristics (Table 3).

In Nutrition domain, Impaired swallowing presented as a related factor disordered eating behaviors (100\%) and, as a defining characteristic, Insufficient chewing (100\%); Risk for deficient fluid volume presented Insufficient fluid intake as the main risk factor (100\%).

Regarding Elimination and exchange domain, Stress urinary incontinence presented as a related factor Weakened supporting pelvic (100\%), as the main defining characteristics, Involuntary leakage of small volume of urine in the absence of overdistended bladder (100\%) and Involuntary leakage of small volume of urine (e.g., with coughing, laughing, sneezing, on exertion) (100\%).

In Activity/rest domain, Impaired walking had pain (91.3\%) as the main related factor; as for defining characteristics, it presented Impaired ability to walk on decline and Impaired ability to walk on incline, with $82.6 \%$ each. In turn, Disturbed sleep pattern had as its main related factor Nonrestorative sleep pattern (100\%) and the defining characteristic Unintentional awakening (86.4\%). 
Regarding Sexuality domain, Sexual dysfunction presented as the main related factor Insufficient knowledge about sexual function (100\%), and, as the most expressive defining characteristic, Alteration in sexual activity (100\%).

Safety/protection domain had three diagnoses: Impaired dentition, Risk for impaired skin integrity and Risk for falls. Impaired dentition was shown to be the main factor related to Difficulty accessing dental care (100\%), while the main defining characteristic was Absence of teeth (96.0\%). Risk for impaired skin integrity presented as main risk factors hydration $(64.7 \%)$ and humidity (64.7\%). The main risk factor for Risk for falls was the difficulty in walking (88.9\%).

Finally, in Comfort domain, Chronic pain was identified. The main related factor was the presence of Injury agent (100\%), and, as defining characteristics, Alteration in ability to continue previous activities (100\%) and Self-report of intensity using standardized pain scale (e.g., Wong-Baker FACES scale, visual analogue scale, numeric rating scale) (100\%).

Table 1- Distribution of nursing diagnoses by NANDA-I domain, Indigenous community, João Câmara, Rio Grande do Norte, Brazil, 2019

\begin{tabular}{|c|c|c|c|c|}
\hline NANDA-I domains (2018-2020) & Mean & Standard deviation & Minimum & Maximum \\
\hline Total nursing diagnoses per elderly & 8.41 & 2.58 & 3 & 14 \\
\hline Health promotion & 0.82 & 0.77 & 0 & 3 \\
\hline Nutrition & 1.39 & 0.80 & 0 & 3 \\
\hline Elimination and exchange & 0.69 & 0.65 & 0 & 2 \\
\hline Activity/rest & 1.43 & 0.94 & 0 & 3 \\
\hline Perception/cognition & 0.24 & 0.47 & 0 & 2 \\
\hline Self-perception & 0.00 & 0.00 & 0 & 0 \\
\hline Roles and relationships & 0.10 & 0.30 & 0 & 1 \\
\hline Sexuality & 0.33 & 0.48 & 0 & 1 \\
\hline Coping/stress tolerance & 0.25 & 0.48 & 0 & 2 \\
\hline Life principles & 0.00 & 0.00 & 0 & 0 \\
\hline Safety/protection & 2.29 & 0.73 & 1 & 4 \\
\hline Comfort & 0.78 & 0.50 & 0 & 2 \\
\hline
\end{tabular}

Table 2 - Distribution of frequencies of nursing diagnoses of indigenous elderly people, Indigenous community, João Câmara, Rio Grande do Norte, Brazil, 2019

\begin{tabular}{|c|c|c|c|}
\hline Nursing diagnosis & $(n=51)$ & $\%$ & $* 95 \% \mathrm{Cl}$ \\
\hline Impaired dentition & 50 & 98.0 & $89.7-99.7$ \\
\hline Risk for impaired skin integrity & 34 & 66.7 & $53.0-78.0$ \\
\hline Chronic pain & 33 & 64.7 & $51.0-76.4$ \\
\hline Risk for deficient fluid volume & 28 & 54.9 & $41.4-67.7$ \\
\hline Impaired swallowing & 23 & 45.1 & $32.3-58.6$ \\
\hline Impaired walking & 23 & 45.1 & $32.3-58.6$ \\
\hline Disturbed sleep pattern & 22 & 43.1 & $30.5-56.7$ \\
\hline Stress urinary incontinence & 21 & 41.2 & $28.8-54.8$ \\
\hline Risk for falls & 18 & 35.3 & $23.6-49.0$ \\
\hline Sexual dysfunction & 17 & 33.3 & $22.0-47.0$ \\
\hline Frail elderly syndrome & 15 & 29.4 & $18.7-43.0$ \\
\hline Overweight & 14 & 27.5 & $17.1-40.9$ \\
\hline Activity intolerance & 13 & 25.5 & $15.5-38.9$ \\
\hline Impaired memory & 12 & 23.5 & $14.0-37.8$ \\
\hline Insomnia & 9 & 17.6 & $9.57-30.3$ \\
\hline Constipation & 8 & 15.7 & $8.17-28.0$ \\
\hline Impaired skin integrity & 8 & 15.7 & $8.17-28.0$ \\
\hline Anxiety & 7 & 13.7 & $6.81-25.7$ \\
\hline Dysfunctional family processes & 4 & 7.8 & $3.1-18.5$ \\
\hline Acute pain & 4 & 7.8 & $3.1-18.5$ \\
\hline Ineffective health maintenance & 3 & 5.9 & $2.0-15.9$ \\
\hline Readiness for enhanced health management & 3 & 5.9 & $2.0-15.9$ \\
\hline Obesity & 3 & 5.9 & $2.0-15.9$ \\
\hline Imbalanced nutrition: less than body requirements & 3 & 5.9 & $2.0-15.9$ \\
\hline Urinary retention & 2 & 3.9 & $1.1-13.2$ \\
\hline Impaired physical mobility & 2 & 3.9 & $1.1-13.2$ \\
\hline Caregiving role strain & 2 & 3.9 & $1.1-13.2$ \\
\hline Fear & 2 & 3.9 & $1.1-13.2$ \\
\hline Impaired oral mucous membrane integrity & 2 & 3.9 & $1.1-13.2$ \\
\hline Ineffective health control & 2 & 3.9 & $1.1-13.2$ \\
\hline Risk for unstable blood glucose level & 1 & 2.0 & $0.3-10.3$ \\
\hline Risk for constipation & 1 & 2.0 & $0.3-10.3$ \\
\hline Bowel incontinence & 1 & 2.0 & $0.3-10.3$ \\
\hline Decreased cardiac output & 1 & 2.0 & $0.3-10.3$ \\
\hline Unstable blood pressure risk & 1 & 2.0 & $0.3-10.3$ \\
\hline Impaired verbal communication & 1 & 2.0 & $0.3-10.3$ \\
\hline Risk for infection & 1 & 2.0 & $0.3-10.3$ \\
\hline
\end{tabular}


Table 3 - Frequency distribution of related factors/risk factors and defining characteristics of nursing diagnoses present in indigenous elderly people. Indigenous community, João Câmara, Rio Grande do Norte, 2019

\begin{tabular}{|c|c|c|c|c|}
\hline Domain & Nursing diagnosis & Related factors/risk factors and Defining characteristics & $\mathbf{n}$ & $\%$ \\
\hline \multirow[t]{3}{*}{ Nutrition } & Impaired swallowing & $\begin{array}{l}\text { Related factors } \\
\text { Disordered eating behaviors }\end{array}$ & 23 & 100 \\
\hline & & $\begin{array}{l}\text { Defining characteristics } \\
\text { Insufficient chewing } \\
\text { Difficulty swallowing } \\
\text { Food falls from mouth }\end{array}$ & $\begin{array}{c}23 \\
22 \\
5\end{array}$ & $\begin{array}{l}100 \\
95.7 \\
21.7\end{array}$ \\
\hline & $\begin{array}{l}\text { Risk for deficient } \\
\text { fluid volume }\end{array}$ & $\begin{array}{l}\text { Risk factors } \\
\text { Insufficient fluid intake }\end{array}$ & 28 & 100 \\
\hline \multirow[t]{2}{*}{$\begin{array}{l}\text { Elimination } \\
\text { and exchange }\end{array}$} & $\begin{array}{l}\text { Stress urinary } \\
\text { incontinence }\end{array}$ & $\begin{array}{l}\text { Related factors } \\
\text { Weakened supporting pelvic }\end{array}$ & 21 & 100 \\
\hline & & $\begin{array}{l}\text { Defining characteristics } \\
\text { Involuntary leakage of small volume of urine in the absence of overdistended bladder } \\
\text { Involuntary leakage of small volume of urine (e.g., with coughing, laughing, } \\
\text { sneezing, on exertion) } \\
\text { Involuntary leakage of small volume of urine in the absence of detrusor contraction }\end{array}$ & $\begin{array}{l}21 \\
21\end{array}$ & $\begin{array}{l}100 \\
100 \\
95.2\end{array}$ \\
\hline \multirow[t]{4}{*}{ Activity/rest } & Impaired walking & $\begin{array}{l}\text { Related factors } \\
\text { Pain } \\
\text { Insufficient muscle strength }\end{array}$ & $\begin{array}{l}21 \\
16\end{array}$ & $\begin{array}{l}91.3 \\
69.6\end{array}$ \\
\hline & & $\begin{array}{l}\text { Defining characteristics } \\
\text { Impaired ability to walk on decline } \\
\text { Impaired ability to walk on incline } \\
\text { Impaired ability to walk on uneven surface } \\
\text { Impaired ability to climb stairs } \\
\text { Impaired ability to navigate curbs } \\
\text { Impaired ability to walk required distance }\end{array}$ & $\begin{array}{l}19 \\
19 \\
18 \\
18 \\
17 \\
6\end{array}$ & $\begin{array}{l}82.6 \\
82.6 \\
78.3 \\
78.3 \\
73.9 \\
26.1\end{array}$ \\
\hline & $\begin{array}{l}\text { Disturbed sleep } \\
\text { pattern }\end{array}$ & $\begin{array}{l}\text { Related factors } \\
\text { Nonrestorative sleep pattern (i.e., due to caregiver responsibilities, } \\
\text { parenting practices, sleep partner) }\end{array}$ & 22 & 100 \\
\hline & & $\begin{array}{l}\text { Defining characteristics } \\
\text { Unintentional awakening } \\
\text { Difficulty initiating sleep } \\
\text { Alteration in sleep pattern } \\
\text { Dissatisfaction with sleep } \\
\text { Feeling unrested } \\
\text { Difficulty in daily functioning }\end{array}$ & $\begin{array}{l}19 \\
17 \\
15 \\
11 \\
4 \\
2\end{array}$ & $\begin{array}{l}86.4 \\
77.3 \\
68.2 \\
50.0 \\
18.2 \\
9.1\end{array}$ \\
\hline \multirow[t]{2}{*}{ Sexuality } & Sexual dysfunction & $\begin{array}{l}\text { Related factors } \\
\text { Insufficient knowledge about sexual function } \\
\text { Misinformation about sexual function }\end{array}$ & $\begin{array}{c}17 \\
1\end{array}$ & $\begin{array}{l}100 \\
5.9\end{array}$ \\
\hline & & $\begin{array}{l}\text { Defining characteristics } \\
\text { Alteration in sexual activity } \\
\text { Alteration in sexual excitation } \\
\text { Alteration in sexual satisfaction } \\
\text { Decrease in sexual desire } \\
\text { Perceived sexual limitation } \\
\text { Change in interest towards others }\end{array}$ & $\begin{array}{l}17 \\
12 \\
8 \\
7 \\
4 \\
1\end{array}$ & $\begin{array}{c}100 \\
70.6 \\
47.1 \\
41.2 \\
23.5 \\
5.9\end{array}$ \\
\hline \multirow[t]{3}{*}{$\begin{array}{l}\text { Safety/ } \\
\text { protection }\end{array}$} & Impaired dentition & $\begin{array}{l}\text { Related factors } \\
\text { Difficulty accessing dental care } \\
\text { Insufficient knowledge of dental health } \\
\text { Insufficient oral hygiene }\end{array}$ & $\begin{array}{l}50 \\
45 \\
44\end{array}$ & $\begin{array}{l}100 \\
90.0 \\
88.0\end{array}$ \\
\hline & & $\begin{array}{l}\text { Defining characteristics } \\
\text { Absence of teeth } \\
\text { Abraded teeth } \\
\text { Excessive oral calculus } \\
\text { Excessive oral plaque } \\
\text { Enamel discoloration }\end{array}$ & $\begin{array}{c}48 \\
35 \\
20 \\
11 \\
5\end{array}$ & $\begin{array}{l}96.0 \\
70.0 \\
40.0 \\
22.0 \\
10.0\end{array}$ \\
\hline & $\begin{array}{l}\text { Risk for impaired } \\
\text { skin integrity }\end{array}$ & $\begin{array}{l}\text { Risk factors } \\
\text { Hydration } \\
\text { Humidity } \\
\text { Excretions } \\
\text { Inadequate nutrition } \\
\text { Extremes of age } \\
\text { Chemical injury agent (e.g., burn, capsaicin, methylene chloride, mustard agent) }\end{array}$ & $\begin{array}{c}22 \\
22 \\
20 \\
2 \\
1 \\
1\end{array}$ & $\begin{array}{c}64.7 \\
64.7 \\
58.8 \\
5.9 \\
2.9 \\
2.9\end{array}$ \\
\hline
\end{tabular}


Table 1 (concluded)

\begin{tabular}{|c|c|c|c|c|}
\hline Domain & Nursing diagnosis & Related factors/risk factors and Defining characteristics & $\mathbf{n}$ & $\%$ \\
\hline \multirow{5}{*}{$\begin{array}{l}\text { Safety/ } \\
\text { protection }\end{array}$} & Risk for falls & Risk factors & & \\
\hline & & Difficulty with gait & 16 & 88.9 \\
\hline & & Decrease in lower extremity strength & 14 & 77.8 \\
\hline & & Incontinence & 9 & 50.0 \\
\hline & & Impaired mobility & 1 & 5.6 \\
\hline \multirow[t]{7}{*}{ Comfort } & Chronic pain & Related factors & & \\
\hline & & Injury agent & 33 & 100 \\
\hline & & Defining characteristics & & \\
\hline & & Alteration in ability to continue previous activities & 33 & 100 \\
\hline & & $\begin{array}{l}\text { Self-report of intensity using standardized pain scale (e.g., Wong-Baker FACES scale, } \\
\text { visual analogue scale, numeric rating scale) }\end{array}$ & 33 & 100 \\
\hline & & Proxy report of pain behavior/activity changes (e.g., family member, caregiver) & 31 & 93.9 \\
\hline & & $\begin{array}{l}\text { Self-report of pain characteristics using standardized pain instrument } \\
\text { (e.g., McGill Pain Questionnaire, Brief Pain Inventory) }\end{array}$ & 29 & 87.9 \\
\hline
\end{tabular}

\section{DISCUSSION}

Safety/protection domain had the highest number of diagnoses present in the participants. This domain refers to the individual being free or exposed to danger, physical injury or damage to the immune system ${ }^{(8)}$. However, when referring to the elderly, they have specific characteristics, due to the decrease in functional reserve, as a result of the senescence process. This process, in turn, makes the elderly more vulnerable to conditions that generate a decline in physical status, with psychological and social consequences, and which can be aggravated and accelerated by the presence of chronic health conditions ${ }^{(16)}$.

Thus, nursing interventions should be provided that minimize the risks and exposure of the elderly to conditions that favor human responses to diagnoses in Safety/protection domain. The resoluteness of these actions is related to adequate guidelines for the elderly, family and network of caregivers, in order to prevent complications. Individual educational actions should be used, as well as actions with the community, thus achieving the expected results in the short, medium and long term, in order to avoid disabilities, dependence and reduce morbidity and mortality ${ }^{(16)}$.

From this perspective, in the proposition and implementation of nursing interventions, the indigenous elderly's culture should be considered, since cultural care allows the construction of a single care plan that is congruent to intercultural dialogue between nurses and indigenous elderly. In this way, there will be a greater possibility of effectiveness in the approach and in the care to be performed ${ }^{(17)}$. In the case of the studied community, indigenous elderly people speak Portuguese, which can facilitate the process of communication and interaction between nurses and elderly people.

The Brazilian National Health Care Policy for Indigenous Peoples (PNASPI - Política Nacional de Atenção à Saúde dos Povos Indígenas) should also be focused. Specifically, PNASPI establishes the recognition of the social and cultural diversity of indigenous peoples, in addition to the consideration and stimulation of their traditional health systems as essential acts in the execution of prevention, promotion and education actions of the professional health system within the Unified System of Health (SUS - Sistema Único de Saúde) ${ }^{(18)}$.

Therefore, the appreciation and articulation of the traditional health practices of these peoples with biomedical knowledge should guide nursing care ${ }^{(17)}$. Nurses, in this context, need to support the process from a theoretical lens that equips their work process in this cross-cultural dialogue. Therefore, the Culture Care Diversity and Universality Theory (CCDUT) conceptualizes components such as culture, worldview, popular care system ${ }^{(19)}$, leading nursing practice from the perspective of interculturality with recognition of the influence of the aforementioned components in health-disease process of the indigenous elderly person.

About the elderly's functional capacity, it is translated by the individual's condition of performing Activities of Daily Living (ADL) independently. On this issue, studies investigating the functional capacity of indigenous elderly people were not identified in the literature, however, in this regard, the NDs identified in this research represent health conditions that signal the existence of some level of functional impairment of the elderly, pointing out facility characteristics of fragility and dependency ${ }^{(20)}$.

Therefore, the presence the ND Impaired dentition in the elderly can result in impaired chewing, make it difficult to swallow food and reduce digestive motility. Damages such as these have already been identified in a study ${ }^{(21)}$, in which there is a high number of extracted teeth in the elderly population, thus pointing to the precariousness of the oral health situation of elderly Brazilians. This case is similar to that of indigenous elderly who, in the present study, had Difficulty accessing dental care as a factor related to the diagnosis.

In this regard, it is known that, in a general context, indigenous populations, when compared to non-indigenous populations, have significantly impaired oral health, and inequalities in access to dental care are largely attributed to social determinants of health. This difficulty of indigenous peoples in accessing oral health care is also representative in the elderly in Potiguara, as it is evident that the most frequent related factor for the ND Impaired dentition was Difficulty accessing dental care.

In the Guarani ethnic group, for example, it was noticed that most indigenous adults had access to dental services predominantly only for tooth extraction ${ }^{(22)}$, which negatively affects oral health during old age.

Regarding the ND Impaired swallowing, it presented as its main defining characteristic Insufficient chewing. The presence of this defining characteristic can be understood as a result of the ND Impaired dentition. The coexistence of these diagnoses 
reflects negatively on chewing and swallowing. This situation is a serious risk for the elderly, making them subject to malnutrition and even bronchoaspiration of food into the lower airways, which can lead to death ${ }^{(23)}$.

The main risk factor for the presence of the ND Risk for deficient fluid volume in indigenous elderly was Insufficient fluid intake, which is justified by the physiological decrease in the thirst mechanism in the elderly, which exposes them to a greater risk of dehydration. It is important to pay attention to this aspect during nursing care for these individuals, concerned with providing an adequate water intake, especially for those chronically ill and bedridden elderly, in which the reduction of thirst mechanisms and even the mobility difficulties needed to have independent access to water ${ }^{(21)}$.

The ND Stress urinary incontinence had a high frequency among the elderly, especially in women. The presence of this ND can cause social isolation, physical and emotional dependence in the elderly, and thus a decrease in quality of life. However, this condition, due to shame or embarrassment, is rarely reported by the elderly during $\mathrm{NC}$, which makes early treatment of symptoms and possible complications difficult. ${ }^{(24)}$. Thus, nurses should investigate the presence of defining characteristics that signal the presence of this ND and then prescribe interventions that minimize this unwanted human response, focusing on its related factors, which, in this study, was the Weakened supporting pelvic.

About the ND Impaired walking, it is known that the aging process causes physiological changes that can, therefore, decrease the elderly's ability to walk. However, if associated with pathological conditions resulting from senility, such as the related factors Pain and Insufficient muscle strength, they can generate immobility, social isolation, dependence and the need for a caregiver to help with $\mathrm{ADL}^{(25)}$.

The presence of the ND Disturbed sleep pattern highlights the need to investigate the presence of clinical indicators of this human response by nurses, both in individual consultations and in elderly groups, with attention to the assessment of defining characteristics such as Unintentional awakening, Difficulty initiating sleep, Alteration in sleep pattern and Dissatisfaction with sleep. In a study ${ }^{(26)}$, it was shown that almost $70 \%$ of the elderly had poor quality sleep at home, which reinforces the need to carry out a detailed sleep assessment of elderly in the community.

Regarding the ND Sexual Dysfunction, the literature shows that the physiological changes presented in aging and elderly's asexuality culture favor constructing a stereotype that sexuality is assigned to the youngest, reproaching the elderly for having desires in the sexual field and pushing them away the search for clarification on this subject ${ }^{(27)}$. These components enhance the Insufficient knowledge about sexual function during old age, the main related factor found for this ND in the studied population.

The ND Risk for impaired skin integrity is related to the fact that the elderly's skin undergoes transformations resulting from the senescence process, resulting in greater fragility and reduced effectiveness of the barrier function, reduced elasticity, loss dermis thickness and epidermis and lower tissue repair capacity ${ }^{(28)}$. These changes, added to urinary incontinence, for example, make the elderly more vulnerable to problems of this nature.
In a study ${ }^{(29)}$ carried with elderly people cared for in $\mathrm{PHC}$, it was identified that advanced age, visual deficits, reduced mental status, history of falls, gait changes, the use of antihypertensive drugs and low ambient lighting are conditions that are risk factors for the ND Risk for falls. However, the literature highlights that falls can be avoided with preventive measures that provide safe environments and, thus, facilitate the elderly's movement.

In a study, chronic pain was present in $58 \%$ of the elderly, corroborating the present study, in which $64.7 \%$ of participants had the ND Chronic pain. It should be noted that the presence of pain in the elderly results in chronic physical disability, with difficulty in performing $A D L$, irritation and even depression ${ }^{(30)}$.

Given the profile of the NDs found, the impairment of the functional capacity of the elderly from the Potiguara ethnic group is evident. From this perspective, it is believed that the living conditions of such a population is permeated by components that favor this phenomenon, as it is considered a multidimensional result that involves demographic, socioeconomic, behavioral and cultural aspects ${ }^{(31)}$.

\section{Study limitations}

The limitations of this study were non-use of statistical tests of association between diagnoses, related factors and defining characteristics as well as failure to deepen the health characteristics and life conditions of Potiguara elderly.

It is recommended to carry out studies that look for the association between the NDs and their components, in order to support, in a more accurate way, the clinical reasoning process of nurses in caring for indigenous elderly. It is also recommended to carry out studies that analyze the living conditions of indigenous elderly people.

\section{Contributions to nursing}

The results of this study contribute to the improvement of nursing care for the indigenous elderly, by enabling prior knowledge of the NDs prevalent in this population, in addition to enhancing the development of clinical reasoning and decision-making by nurses through the implementation of NC in PHC. It is also worth highlighting the favoring of language standardization with the naming and documentation of phenomena of interest to the nursing course in the context of indigenous health.

\section{CONCLUSIONS}

By showing the profile of nursing diagnosis found in Potiguara indigenous elderly in the community, it was identified that the profile reveals the impairment of participants'functional capacity, with the largest number of diagnoses being in Safety/protection domain. Given this reality, it is clear that nursing diagnosis point to conditions that, if not treated and/or monitored by nurses in the context of PHC, can result in a high degree of dependence and reduced life expectancy of these elderly. In this sense, the need for monitoring of indigenous elderly by nurses is reaffirmed, especially with actions aimed at prevention and control of diseases, avoiding further complications and installation of 
fragility and dependence. Finally, the importance of identifying nursing diagnosis is highlighted as a key step for the nursing consultation development, since NDs guide nurses' therapeutic decision-making.

\section{SUPPLEMENTARY MATERIAL}

The present manuscript is the result of the Dissertation "Human responses and self-care culture of indigenous elderly: a mixed methods study" available in: https://www.repositorio.ufrn.br/ handle/123456789/28531

\section{FUNDING}

Master's Level Graduate Scholarship from the Brazilian National Council for Scientific and Technological Development (Conselho Nacional de Desenvolvimento Científico e Tecnológico).

\section{ACKNOWLEDGMENT}

To the Study and Research Group in Nursing, Health and Aging of Universidade Federal do Rio Grande do Norte and to the indigenous elderly of Rio Grande do Norte.

\section{REFERENCES}

1. Veras RP, Oliveira M. Aging in Brazil: the building of a healthcare model. Cienc Saude Colet. 2018;23(6):1929-36. https://doi. org/10.1590/1413-81232018236.04722018

2. Instituto Brasileiro de Geografia e Estatística (IBGE). Projeção da população do Brasil e das unidades da federação. 2020 [cited 2020 Mar 12]. Available from: https://www.ibge.gov.br/apps/populacao/projecao/

3. Rissardo LK, Carreira L. New Horizons: a look at the old professional care of the indigenous. Cienc Cuidado Saude. 2016;15(3):396. https:// doi.org/10.4025/cienccuidsaude.v15i3.34622

4. Schenker M, Costa DH. Advances and challenges of health care of the elderly population with chronic diseases in primary health care. Cienc Saude Colet. 2019;24(4):1369-1380. https://doi.org/10.1590/1413-81232018244.01222019

5. Fiorati RC, Arcêncio RA, Souza LB. Social inequalities and access to health: challenges for society and the nursing field. Rev Latino-Am Enfermagem. 2016;24:e2687. https://doi.org/10.1590/1518-8345.0945.2687

6. Conselho Federal de Enfermagem. Resolução COFEN n 358/2009. Dispõe sobre a Sistematização da Assistência de Enfermagem e a implementação do Processo de Enfermagem em ambientes, públicos ou privados, em que ocorre o cuidado profissional de Enfermagem, e dá outras providências [Internet]. Brasília, DF: COFEN; 2009[cited 2020 Mar 12]. Available from: http://www.cofen.gov.br/ resoluocofen-3582009_4384.html

7. Abrahão AL, Amaral IT. Nursing consultation in family health strategy, increasing the recognition of the distinct forms of action: an integrative review. Rev Pesqui Cuidado Fundam. 2017;9(4):899-906. https://doi.org/10.9789/2175-5361.2017.v9i4.899-906

8. Diagnósticos de enfermagem da NANDA-I: definições e classificação 2018-2020 [Internet]. 11a ed. Porto Alegre: Artmed; 2018 [cited 2020 Mar 12]. Available from: http://nascecme.com.br/2014/wp-content/uploads/2018/08/NANDA-I-2018_2020.pdf

9. Diniz IA, Cavalcante RB, Otoni A, Mata LRF. Perception of primary healthcare management nurses on the nursing process. Rev Bras Enferm. 2015;68(2):206-13. https://doi.org/10.1590/0034-7167.2015680204i

10. Silva A, Rosa TEC, Batista LE, Kalckmann S, Louvison MCP, Teixeira DSC, et al. Racial inequities and aging: analysis of the 2010 cohort of the health, welfare and aging study (SABE). Rev Bras Epidemiol. 2018;21(Suppl 2):e180004. https://doi.org/10.1590/1980-549720180004.supl.2

11. Ministério da Saúde (BR). Agenda nacional de prioridades de pesquisa em saúde. Brasília, DF; 2015.

12. Hirano GSB, Lopes CT, Barros ALBL. Development of research on nursing diagnoses in Brazilian graduate programs. Rev Bras Enferm. 2019;72(4):926-32. https://doi.org/10.1590/0034-7167-2018-0259

13. Risner PB, Christensen PJ, Kenney JM. Nursing diagnosis: diagnostic sistements. In: Christensen PJ, Kenney JM. Nursing Process: application of conceptual modes. St. Louis: Mosby; 1990. p. 132-57.

14. Novaes ES, Torres MM, Oliva APV. Nursing diagnoses in surgical clinic. Acta Paul Enferm. 2015;28(1):26-31. https://doi. org/10.1590/1982-0194201500006

15. Silva DVA, Sousa INM, Rodrigues CAO, Pereira FAF, Gusmão ROM, Araújo DD. Nursing diagnoses in a home-based program: cross-mapping and NANDA-I taxonomy. Rev Bras Enferm. 2019;72(3):584-91. https://doi.org/10.1590/0034-7167-2018-0323

16. Guedes HM, Nakatami AYK, Santana RF, Bachion MM. Identificação de diagnósticos de enfermagem do domínio segurança/proteção em idosos admitidos no sistema hospitalar. Rev Eletronica Enferm. 2009;11(2):249-256. https://doi.org/10.5216/ree.v11.46935

17. Rissardo LK, Alvim NAT, Marcon SS, Carreira L. Práticas de cuidado ao idoso indígena: atuação dos profissionais de saúde. Rev Bras Enferm. 2014;67(6):920-7. https://doi.org/10.1590/0034-7167.2014670609

18. Fundação Nacional de Saúde (BR). Política nacional de atenção à saúde dos povos indígenas [Internet]. Brasília, DF: MS; 2002 [cited 2020 Nov 27]. Available from: http://bvsms.saude.gov.br/bvs/publicacoes/politica_saude_indigena.pdf

19. Assis Silva CJ, Pereira WC, Neves Jr TT, Silva VGF, Menezes RMP. Práticas do enfermeiro no cuidado à pessoa indígena em processo de saúde-adoecimento: reflexos da assistência transcultural. In: Heufemann NEC, Ferla AA, Lima KMS, Martins FM, Lemos SM. 
Saúde indígena: educação, gestão e trabalho. Porto Alegre: Rede UNIDA; 2020. (Coleção saúde e Amazônia). p. 221-25. https://doi. org/1018310/9786587180144

20. Maciel GMC, Santos RS, Santos TM, Menezes RMP, Vítor AF, Lira ALBC. Avaliação da fragilidade no idoso pelo enfermeiro: revisão integrativa. Rev Enferm Centro Oeste Mineiro. 2016;6(3):2430-38. https://doi.org/10.19175/recom.v6i3.1010

21. Clares JWB, Freitas MC. Diagnósticos de enfermagem do domínio nutrição identificados em idosos da comunidade. Rev Eletronica Enferm. 2013;15(4):940-7. https://doi.org/10.5216/ree.v15i4.20513

22. Baldisserotto J, Ferreira AM, Warmling CM. Condições de saúde bucal da população indígena guarani moradora no Sul do Brasil. Cad Saude Colet. 2019;27(4):468-75. https://doi.org/10.1590/1414-462×201900040354

23. Ministério da Saúde (BR). Envelhecimento e saúde da população idosa. Brasília, DF: MS; 2006.

24. Silva GO, Peixoto LCP, Souza DA, Santos ALS, Aguiar ACSA. Repercussions of chronic diseases on the mental health of elderly people. Rev Enferm UFPE. 2018;12(11):2923-32. https://doi.org/10.5205/1981-8963-v12i11a234540p2923-2932-2018

25. Marques-Vieira CMA, Sousa LMM, Carias JFMM, Caldeira SMA. Nursing diagnosis "impaired walking" in elderly patients: integrative literature review. Rev Gaucha Enferm. 2015;36(1):104-11. https://doi.org/10.1590/1983-1447.2015.01.48602

26. Monteiro NT, Ceolim MF. Quality of sleep of the aged at home and in hospital. Texto Contexto Enferm. 2014;23(2):356-64. https://doi. org/10.1590/0104-07072014000190013

27. Alencar DL, Marques APO, Leal MCC, Vieira JCM. Fatores que interferem na sexualidade de idosos: uma revisão integrativa. Cienc Saude Colet. 2014;19(8):3533-42. https://doi.org/10.1590/1413-81232014198

28. Clares JWB, Guedes MVC, Silva LF, Nóbrega MML, Freitas MC. Subset of nursing diagnoses for the elderly in Primary Health Care. Rev Esc Enferm USP. 2016;50(2):270-6. https://doi.org/10.1590/S0080-623420160000200013

29. Kuznier TP, Souza CC, Chianca TCM, Ercole FF, Alves M. Fatores de risco para quedas descritos na taxonomia da NANDA-I para uma população de idosos. Rev Enferm Centro Oeste Mineiro. 2015;5(3):1855-70. https://doi.org/10.19175/recom.v5i3.783

30. Oliveira RR, Ribeiro VS, Godoy GS, Cavalcante AMRZ, Stival MM, Lima LR. Diagnósticos de enfermagem de idosos cadastrados em estratégias de saúde da família em um município do interior de Goiás. Rev Enferm Centro Oeste Mineiro. 2011;1 (2):248-59. https://doi.org/10.19175/ recom.v0i0.85

31. Aguiar VFF, Santos BSC, Gomes DCN, Tavares TCA. Avaliação da capacidade funcional e qualidade de vida do idoso no Brasil residente em comunidade. Rev Enferm Referencia. 2019;serIV(21):59-65. https://doi.org/10.12707/RIV19011 